\title{
Normoalbuminuric diabetic kidney disease: a distinct entity?
}

\section{SV Madhu ${ }^{1}$}

Published online: 22 May 2019

(C) Research Society for Study of Diabetes in India 2019

Diabetic kidney disease (DKD) is the major cause of renal disease due to hyperglycemia. Worldwide, approximately $40 \%$ of people with diabetes develop DKD. Presence of persistent albuminuria in urine is the initial clinical indication of DKD. Of the major pathways known to be involved in the development and progression of DKD, the renin-angiotensinaldosterone system (RAAS) has been considered as the most important pathway as it plays a central role in maintaining blood pressure, glomerular pressure, and fluid and electrolyte balance via angiotensin II. During development of diabetic nephropathy (DN), there is increased formation of angiotensin II, by the action of ACE, which further results in renal vascular constriction via activation of its receptor ATR1. However, activation of ATR2 ensues beneficial effects including vasodilation, antiinflammatory, and antiproliferative actions [1].

Tsalamandris and his coworkers observed for the first time in 1994 that few type II DM patients displayed no significant proteinuria but had renal insufficiency and developed DKD (i.e., estimated glomerular filtration rate (eGFR) $<60 \mathrm{~mL} / \mathrm{min} /$ $1.73 \mathrm{~m}^{2}$ ) [2]. This has been described as normoalbuminuric diabetic kidney disease (NADKD) or diabetic kidney disease without proteinuria where albuminuria does not associate with impairment of kidney function. The ADA criteria for diagnosis of DKD now involve the presence of eGFR $<60 \mathrm{~mL} / \mathrm{min} /$ $1.73 \mathrm{~m}^{2}$ or the presence of UAE $>30 \mathrm{mg} / 24 \mathrm{~h}$ [3]. In patients with nonalbuminuric diabetic kidney disease, risk factors include obesity, hypertension, high TG levels, sex, poor glycemic control, and glomerular hyperfiltration $[4,5]$ that may play a role in nephrosclerosis. Prevalence of NADKD varies from 14.29 to $56.6 \%$ among diabetic patients with different ethnicities $[6,7]$. Macroangiopathy is found to be more prevalent in patients with NADKD [8]. Boeri et al. also observed that intrarenal arteriosclerosis is the main cause of renal

SV Madhu

drsvmadhu@gmail.com

1 Department of Endocrinology, Centre for Diabetes, Endocrinology and Metabolism, University College of Medical Sciences \& GTB Hospital, New Delhi, India impairment in NIDDM patients independent of albuminuria [9], and this may partly cause eGFR decline in these patients. Several studies also suggest that decline in renal function is mainly due to interstitial injury (a pathological change in DN) [10] as compared with glomerular injury [11]. Hence, eGFR decline may be a consequence of interstitial injury in DM patients and tubulointerstitial injury may be more important in the development of NADKD. Mesangial matrix proliferation, increased glomerular fibrosis, thickening of basement membrane, and increased type IV collagen in the interstitium and glomeruli are some pathological changes that were demonstrated in NADKD rats and patients [12]. Moreover, a faster eGFR decline in albuminuric DM patients was observed as compared with patients with NADKD [13]. Urinary NGAL and FABP are the important indicators of tubular injury in the kidney [14] that may be helpful in the diagnosis of NADKD.

Activation of ATR1 plays an important role in the pathogenesis of renal tissue injury. In an earlier study, it has been observed that hyperglycemia activates RAAS and contributes to renal fibrosis [15]. Ang II, the major mediator of kidney injury, displays majority of its deteriorating effects like generation of ROS, tissue inflammation, and fibrosis via activation of ATR1 [16]. Increased expression of ATR1 has been reported in the in vivo model of glomerular capillary hypertension in podocytes of the remnant kidney [17]. It has been observed that activated NF- $\mathrm{KB}$ complexes are largely situated in mesangial, tubuloepithelial, and endothelial cells [18] and promote renal inflammation by macrophage infiltration in a model of diabetic nephropathy [19] and treatment with ATR1 antagonist partly diminished NF- $\mathrm{kB}$ activation [20]. Also, treatment with ATR1 antagonist in kidney arterioles led to increased expression of protective ACE2 [21].

Among RAAS genes, ACE gene is the most extensively studied gene, and I/D polymorphism of ACE gene is found to be strongly associated with the activity of ACE [22] in DN patients. AGTR1 gene expression pattern also demonstrates significant association with DN [23]. Increased mRNA levels of ATR1 gene have been found to be associated with $\mathrm{C}$ allele of A1166C polymorphism [24]. Earlier studies have confirmed the significant association of A1166C polymorphism of ATR1 
gene with DN [25]. However, contrasting reports regarding association of ATR1 and DN also exist in literature [26].

In this issue, Viswanathan et al. [27] report the clinical and biochemical features of patients with NADKD from South India and their relation with ATR1 receptor polymorphisms. The finding of significant differences in clinical and biochemical profiles as well as higher cystatin $\mathrm{C}$ and a significant association of AGTR1 A1166C receptor polymorphism with normoalbuminuric DKD suggests that this entity could have a different underlying pathophysiology. It could also be possible that cystatin $\mathrm{C}$ or other biomarkers in the blood or the urine could serve as earlier indicators of DKD than albuminuria. Whether there is a distinct genetic basis for this condition is unclear and cannot be said with any degree of certainty from this study. Future prospective studies with much larger sample sizes might answer this question and need to be undertaken.

\section{References}

1. Widdop RE, Jones ES, Hannan RE, Gaspari TA. Angiotensin AT2 receptors: cardiovascular hope or hype? Br J Pharmacol. 2003;140(5):809-24.

2. Tsalamandris C, Allen TJ, Gilbert RE, Sinha A, Panagiotopoulos S, Cooper ME, et al. Progressive decline in renal function in diabetic patients with and without albuminuria. Diabetes. 1994;43(5):64955 .

3. American Diabetes, A. Standards of medical care in diabetes2015 abridged for primary care providers. Clin Diabetes : Publ Am Diabetes Assoc. 2015;33(2):97-111.

4. Yokoyama H, Sone H, Oishi M, Kawai K, Fukumoto Y, Kobayashi $\mathrm{M}$, et al. Prevalence of albuminuria and renal insufficiency and associated clinical factors in type 2 diabetes: the Japan Diabetes Clinical Data Management study (JDDM15). Nephrol Dial Transplant. 2008;24(4):1212-9.

5. Kramer CK, Leitao CB, Pinto LC, Silveiro SP, Gross JL, Canani LH. Clinical and laboratory profile of patients with type 2 diabetes with low glomerular filtration rate and normoalbuminuria. Diabetes Care. 2007;30(8):1998-2000.

6. Penno G, et al. Clinical significance of nonalbuminuric renal impairment in type 2 diabetes. J Hypertens. 2011;29(9):1802-9.

7. Kramer HJ, Nguyen QD, Curhan G, Hsu CY. Renal insufficiency in the absence of albuminuria and retinopathy among adults with type 2 diabetes mellitus. Jama. 2003;289(24):3273-7.

8. MacIsaac RJ, Panagiotopoulos S, McNeil KJ, Smith TJ, Tsalamandris $\mathrm{C}$, Hao $\mathrm{H}$, et al. Is nonalbuminuric renal insufficiency in type 2 diabetes related to an increase in intrarenal vascular disease? Diabetes Care. 2006;29(7):1560-6.

9. Boeri D, Derchi LE, Martinoli C, Simoni G, Sampietro L, Storace $\mathrm{D}$, et al. Intrarenal arteriosclerosis and impairment of kidney function in NIDDM subjects. Diabetologia. 1998;41(1):121-4.

10. Lane PH, Steffes MW, Fioretto P, Mauer SM. Renal interstitial expansion in insulin-dependent diabetes mellitus. Kidney Int. 1993;43(3):661-7.

11. Ekinci EI, Jerums G, Skene A, Crammer P, Power D, Cheong KY, et al. Renal structure in normoalbuminuric and albuminuric patients with type 2 diabetes and impaired renal function. Diabetes Care. 2013;36(11):3620-6.

12. Yagil C, Barak A, Ben-Dor D, Rosenmann E, Bernheim J, Rosner $\mathrm{M}$, et al. Nonproteinuric diabetes-associated nephropathy in the Cohen rat model of type 2 diabetes. Diabetes. 2005;54(5):1487-96.
13. Boronat M, García-Cantón C, Quevedo V, Lorenzo DL, LópezRíos L, Batista F, et al. Non-albuminuric renal disease among subjects with advanced stages of chronic kidney failure related to type 2 diabetes mellitus. Ren Fail. 2014;36(2):166-70.

14. Alter ML, Kretschmer A, von Websky K, Tsuprykov O, Reichetzeder C, Simon A, et al. Early urinary and plasma biomarkers for experimental diabetic nephropathy. Clin Lab. 2012;58(7-8):659-71.

15. Chen, C.-M., S.-H. Juan, and H.-C. Chou, Hyperglycemia activates the renin-angiotensin system and induces epithelial-mesenchymal transition in streptozotocin-induced diabetic kidneys. J ReninAngiotensin-Aldosterone Syst, 2018. 19(3): p. 147032031880 $3009,147032031880300$.

16. Noronha IL, Fujihara CK, Zatz R. The inflammatory component in progressive renal disease - are interventions possible? Nephrol Dial Transplant. 2002;17(3):363-8.

17. Durvasula RV, Petermann AT, Hiromura K, Blonski M, Pippin J, Mundel P, et al. Activation of a local tissue angiotensin system in podocytes by mechanical strain. Kidney Int. 2004;65(1):30-9.

18. Ruiz-Ortega M, Lorenzo Ó, Rupérez M, Blanco J, Egido J. Systemic infusion of angiotensin II into normal rats activates nuclear factor-KB and AP-1 in the kidney: role of AT1 and AT2 receptors. Am J Pathol. 2001;158(5):1743-56.

19. Lee FT, Cao Z, Long DM, Panagiotopoulos S, Jerums G, Cooper $\mathrm{ME}$, et al. Interactions between angiotensin II and NF- $\mathrm{BB}-$ dependent pathways in modulating macrophage infiltration in experimental diabetic nephropathy. J Am Soc Nephrol. 2004;15(8):2139-51.

20. Esteban V, Lorenzo O, Rupérez M, Suzuki Y, Mezzano S, Blanco J, et al. Angiotensin II, via AT1 and AT2 receptors and NF- $\mathrm{BB}$ pathway, regulates the inflammatory response in unilateral ureteral obstruction. J Am Soc Nephrol. 2004;15(6):1514-29.

21. Soler MJ, Ye M, Wysocki J, William J, Lloveras J, Batlle D. Localization of ACE2 in the renal vasculature: amplification by angiotensin II type 1 receptor blockade using telmisartan. Am J Physiol-Renal Physiol. 2009;296(2):F398-405.

22. Nikzamir A, Nakhjavani M, Esteghamati A, Rashidi A. Correlates of ACE activity in macroalbuminuric type 2 diabetic patients treated with chronic ACE inhibition. Nephrol Dial Transplant. 2007;23(4):1274-7.

23. Chen $\mathrm{Z}$, et al. Identification of potential candidate genes for hypertensive nephropathy based on gene expression profile. BMC Nephrol. 2016;17(1):149.

24. Chandra S, et al. Association of angiotensin II type 1 receptor (A1166C) gene polymorphism and its increased expression in essential hypertension: a case-control study. PLoS One. 2014;9(7): e101502-e101502.

25. Shah VN, Cheema BS, Sharma R, Khullar M, Kohli HS, Ahluwalia TS, et al. ACAC $\beta$ gene (rs2268388) and AGTR1 gene (rs5186) polymorphism and the risk of nephropathy in Asian Indian patients with type 2 diabetes. Mol Cell Biochem. 2013;372(1):191-8.

26. Moradi M, et al. AT1R A1166C variants in patients with type 2 diabetes mellitus and diabetic nephropathy. J Nephropathol. 2015;4(3):69-76.

27. Viswanathan V, Krishnamoorthy E, Kumpatla S, et al. Clinical and biochemical characteristics and the association of angiotensin type 1 receptor with normoalbuminuric chronic kidney disease among South Indian type 2 diabetes population. Int J Diabetes Dev Ctries. 2019. https://doi.org/10.1007/s13410-019-00719-0.

Publisher's note Springer Nature remains neutral with regard to jurisdictional claims in published maps and institutional affiliations. 